\title{
Institutional Features of Interaction of the State and of Natural Monopolies
}

\author{
Grunichev A.S.a \\ Mierin L.A. b \\ Yagudin R.Kh.c \\ Fakhrutdinov R.M.d \\ ${ }^{a}$ Kazan Federal University, Institute of Management, Economics and Finance, Kazan, 420008, Russia \\ Email: hulia_k@mail.ru \\ b Saint-Petersburg State University of Economics, Saint-Petersburg, 191023, Russia \\ c Republican Clinical Hospital, 420064, Kazan, Orenburg tract, 138, Russia \\ a Graduate School of Management is St. Petersburg State University, Volkhovskiy Per.3 St.Petersburg 199004, Russia
}

\section{Doi:10.5901/mjss.2015.v6n1s3p73}

\section{Abstract}

The author examines institutional, as well as economic approaches to natural monopolies investigation. Institutional peculiarities of their development are analyzed; the structure of the institutional environment of natural monopolies is characterized. The problems of regulation of natural monopolies are identified. The process of regulation of natural monopolies is considered through the prism of the effect of dynamic inconsistency. The formal and informal interaction of natural monopolies and government agencies are defined. It is proposed a step-by-step state regulation of natural monopolies with due regard for market instructions maturity. There are formulated additional measures of state regulation of natural monopolies.

Keywords: natural monopoly, institutional approach, the structure of the institutional environment, state regulation of natural monopolies, investment activities of natural monopolies, competitive relations

\section{Introduction}

The overall goal of socio-economic reforms in the Russian Federation is to create an institutional system that generates such norms and standards of conduct and regulation of natural monopolies, which would increase the quality level of all strata of the population. The size of their income is greater, the greater the benefit of their work brings to society [9].

There are elements of a regulated market economy in all industrialized countries currently. This fact implies a certain degree of intervention of different institutional structures in market mechanisms. In this regard, the application of the institutional approach to the analysis of the interaction of natural monopolies and the state in the conditions of an open economy is particularly relevant [8].

Understanding the functioning of the economic system and the economic mechanism of the economy requires the analysis of very complex interactions between society and economy, natural monopolies of and State or together as part of the economic system in terms of the institutional approach. The relationship between society and economy are determined by a set of institutional constraints that define the mode of functioning of the economic system. The Institutions are the key to understanding the relationship between society and economy and the impact of these relationships on economic growth. Ultimately, institutions are the fundamental factors in the functioning of economic systems in the long term [5].

\section{Theory}

To determine the institutional features of the interaction of natural monopolies and state it is advisable to determine the structure. Under institutional structure refers to the set of institutions, which are in close relationship and develop together with it. (Fig. 1).

The structure of the institutional environment in relation to natural monopolies can be represented in a diagram 
The structure of institutional environment includes: legislation, regulations, mandatory for businesses; enforcement mechanism, ensuring adherence to the rules of (court system); unwritten laws, unspoken rules and rules of conduct of business entities, rules, customs, not enshrined in law but applied in economic practice, tradition, historical and national characteristics, religious and cultural factors; organization («players»), in collaboration with each other [12].

The role of the state is a consistency of economic processes, the whole course of social reproduction, conscious centralized influence on economic processes and entities, including natural monopolies. The recognition of the state as a market entity gives grounds to consider it as a phenomenon of basic, economic, integral attribute of market economic mechanism.

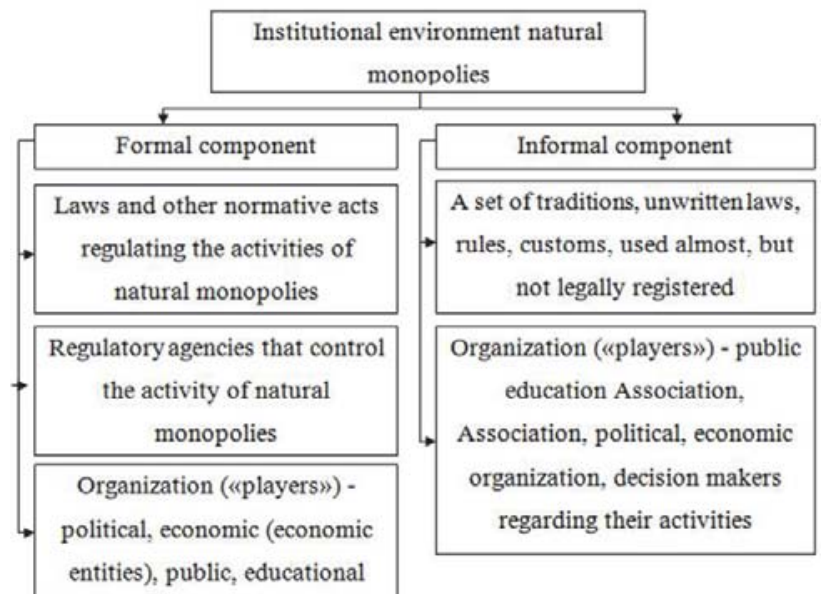

Fig.1. The institutional environment of natural monopolies [1]

Economic efficiency of activity of natural monopolies defines formal rules, informal norms and enforcement system for compliance with the established conditions. The state, as the initiator of formal economic institutions must be in constant interaction with business entities. This condition is necessary for real action legally binding standards and their compliance with informal rules [11].

The complexity of the regulation of joint stock companies in the natural monopoly sectors - for example, OJSC «Rostelecom» and OJSC «Gazprom», OJSC «Svyazinvest», OJSC «Russian Railways», is that the state involved in this process in several guises. It is interested in improving the financial performance of these companies as an owner of companies and the receiver of taxes to the budget [2].

Indicators of activities of natural monopolies in the Russian Federation in January-December 2013

Table 1: Balanced financial result (profit minus loss) of companies spheres of natural monopolies in the Russian Federation for January-December 2013

\begin{tabular}{|l|c|c|c|}
\hline & $\begin{array}{c}\text { Balanced financial result } \\
\text { (profit minus loss) for the } \\
\text { reporting period, thousand } \\
\text { rubles }\end{array}$ & $\begin{array}{c}\text { Balanced financial result (profit } \\
\text { minus loss) for the corresponding } \\
\text { period last year, thousand rubles }\end{array}$ & $\begin{array}{c}\text { The growth rate in \% to } \\
\text { the corresponding } \\
\text { period last year }\end{array}$ \\
\hline transportation of oil and oil products through pipelines & 210217642 & 220711845 & 95,2 \\
\hline the transportation of gas through pipelines & 1032817056 & 900926772 & 114,6 \\
\hline transmission services electric (thermal) energy & 633965130 & 535414546 & 118,4 \\
\hline rail transportation & 18533517 & 66459174 & 27,9 \\
\hline port services (river and sea transport) & 39720192 & 67674893 & 88,7 \\
\hline airport services and the services of transport terminals & 73708228 & 87826687 & 156,3 \\
\hline Services public postal & 3642397 & 2330904 & 166,2 \\
\hline services public telecommunications & 356246274 & 214343469 & 113,7 \\
\hline $\begin{array}{l}\text { services for operational dispatch management in the } \\
\text { electric power industry }\end{array}$ & 3327939 & 2928156 & 2 \\
\hline
\end{tabular}

Source: Main indicators of activity of natural monopolies / Federal state statistics service of the Russian Federation. 2014. (http://www.gks.ru/wps/wcm/connect/rosstat_main/rosstat/ru/statistics/publications/catalog/33857a8044cd99bda132f733421f 06f5). 
Table 2: The turnover of the organizations in the spheres of natural monopolies in the Russian Federation in JanuaryDecember 2013, thousand rubles

\begin{tabular}{|c|c|c|c|}
\hline & \multicolumn{2}{|c|}{ In fact, during the } & \multirow{2}{*}{$\begin{array}{l}\text { The growth rate in } \% \\
\text { to the corresponding } \\
\text { period last year }\end{array}$} \\
\hline & $\begin{array}{c}\text { The period from the beginning } \\
\text { of the reporting year }\end{array}$ & $\begin{array}{l}\text { The corresponding } \\
\text { period of last year }\end{array}$ & \\
\hline transportation of oil and oil products through pipelines & 1253469476 & 1192375257 & 105,1 \\
\hline the transportation of gas through pipelines & 6423227540 & 5911342687 & 108,7 \\
\hline transmission services electric (thermal) energy & 7413078243 & 7021733098 & 105,6 \\
\hline rail transportation & 1280260560 & 1266013959 & 101,1 \\
\hline port services (river and sea transport) & 222912901 & 230370971 & 96,8 \\
\hline airport services and the services of transport terminals & 409705993 & 381564843 & 107,4 \\
\hline services public postal & 131836394 & 125062867 & 105,4 \\
\hline services public telecommunications & 1724267844 & 1708232560 & 100,9 \\
\hline services for operational dispatch management in the electric power industry & 23931467 & 21739840 & 110,1 \\
\hline
\end{tabular}

Source: Main indicators of activity of natural monopolies / Federal state statistics service of the Russian Federation. 2014. (http://www.gks.ru/wps/wcm/connect/rosstat_main/rosstat/ru/statistics/publications/catalog/33857a8044cd99bda132f733421f 06f5).

At the same time as the conductor of public interest the state is on the side of the consumer and should not allow significant price increases. This requires one of the important macroeconomic control functions - maintaining price stability in the country. At the same time, infrastructural nature of natural monopolies and the significance of the external effects of their activities require maintaining the required level of investments that must be provided appropriate funding sources.

Therefore, the regulation of natural monopolies, the state must combine the goals of efficiency, equity and sustainability in the long term. Ultimately, they correspond to the fundamental interests of three interacting entities (producers, consumers and government), and contribute to balance their interests. At the same time, this ideal scheme adjusts the reality. The difficulty of regulating natural monopolies Federal and local level is that they show a pronounced opportunistic behavior in relation to state and society in the form of inflated costs and hide information from the regulatory body (incomplete or inaccurate information) and direct consumers. You should also consider that the regulation of the entire set of transactions between counterparties in the sphere of natural monopolies may be accompanied by the growth of transaction costs, which reduces the effectiveness of this regulation [4].

In addition, the regulation of natural monopolies, as in any other regulation, may be a manifestation of the effect of dynamic inconsistency: taken once a standard package of norms at the time of its greatest impact may be less effective or even dangerous due to the structural and institutional changes in the economy. And the adjustment of this package will begin to interfere with work «blocking effect» once adopted standard. Besides, there is always the possibility of the manifestation of the so-called «law of unintended consequences» [10].

The informal interaction of natural monopolies with government agencies is a counter character. On the one hand, the state has an "impact" on natural monopolies in the form of administrative-bureaucratic, personnel decisions, the allocation of natural monopolies unusual features, support requirements of certain commercial structures, the imposition run monopolies political problems. On the other hand, the industries of natural monopolies use the state to search for and assign political-economic rent and lobby their economic interests in the authorities actively. As a rule facts lobbying are confirmed by indirect evidence.

In general, rent-seeking behavior leading to reduced production volumes and price disparity, and wasting rent in lobbying further reduces social welfare. In addition, it leads to long-term consequences: deterioration of the institutional environment in general, the maintenance of inefficient management and reduction in the quality of political institutions.

State regulation of natural monopolies shall be accompanied by systemic changes in the economy, the development of market principles of its functioning, the creation of a favorable institutional environment for their development. At the same time, it must fit into the general concept of state regulation of the economy and to match the maturity of market institutions in general.

\section{Results}

State regulation of natural monopolies, should include three stages:

1) Maintaining a symbiotic (semi-market) institutes corrective nature in the short term:

- restriction of transactions with property (including related to the sale of shares to foreigners); 
- state joint financing of investment and innovation [3];

- temporary preservation practice of cross-subsidization to maintain fair prices for different consumer segments.

State regulation of investment activity of subjects of natural monopolies should be focused on the strengthening of supervision effective and targeted use of investment funds in the form of grants and targeted funding, forecasting needs in investment capital and direct (by order of the target equity grants, loans and indirect taxes, patents) stimulation of research and development work, the creation of favorable innovation climate in the economy [6].

2) To create the basic institutions of a market economy (including the basic rules of the game associated with the elimination of market imperfections):

- strengthening of civil institutions and civil society,

- $\quad$ the adoption of laws to help fight against bureaucracy;

- overcoming informal practices in the regulation of natural monopolies;

- improvement of standardization and certification in the activities of natural monopolies;

- the introduction of mandatory independent audit companies naturally monopolistic industries;

- creating a framework for the protection of consumers ' rights in collaboration with the natural monopoly entities, aimed, inter alia, to overcome various exotic monopolistic practices (setting high fees for connection services, the imposition of additional services, unjustified disconnection of consumers ' access to welfare and other).

3) The development of complementary market institutions in the long term:

- ensuring equal access to the market of alternative providers that are willing to offer lower rates than the subjects of natural monopolies;

- organization bidding for the franchise (franchise), the creation of market-based institutional framework for the purchase and sale of contractual rights of access to transmission and distribution transportation systems;

- the formation of a civilized market for private companies and foreign companies by organizing futures and spot trading products of natural monopolies on one or more commodity and stock exchanges;

- the establishment of a voluntary information space providers and consumers of natural monopoly entities;

- improved procedures for the coordination of economic interests of suppliers and consumers of goods (services) on the regulated segments of the monopoly market;

- establishment of legal principles for the compensation of losses of natural monopoly structures.

\section{Conclusions}

An additional measure of state regulation should be indicative planning, orienting natural monopoly on long-term macroeconomic perspective, which will allow for better development of their development strategies [7].

\section{References}

Amable B. Instituonal Complementarity and Diversity of Social System of Innovation and Production. Review of International Political Economy, 2009, vol. 7, №4.

Fakhrutdinova, E., Kolesnikova, J., Kiselkina, O. Issues of commercialization of intangible property rights in Russia /World Applied Sciences Journal. 2013. №27 (13), pp. 72-76.

Fakhrutdinova, E., Mokichev, S., Kolesnikova, J. The influence of cooperative connections on innovation activities of enterprises // World Applied Sciences Journal 2013. № 27 (2), pp. 212-215.

Joscow, P.L. Transaction Cost Economics, Antitrust Rules and Remedies // Journal of Law Economics and Organization. 2010. № 18. pp. 95-116.

Kahn A. A. The Economics of Regulation: and Institutions // Economic Principles. New York. 1993. Vol. 1.

Moussa H., Davies J.E. Natural Monopoly and the Invisible Hand // Economic-Studies-Quarterly. 2003. vol. 39. pp. 118-131.

Panzar J.C., Willig R.D. Free Entry and Stability of Natural Monopoly // Bell Journal of Economics. 2007. vol. 8. pp. 17-21.

Posner R.A. Natural Monopoly and its regulation // Stanford Law Review. 2009. vol. 21. pp. 548-643.

Richard A. Posner R.A. Natural monopoly and its Regulation / A. Richard, R.A. Posner. GATO Institute, 2010. 647 p.

Sharkey W. The theory of natural monopoly. New York, 2005.

Slay B., Capelik V. The Struggle for Natural Monopoly Reform in Russia // Post Soviet Geography and Economics. 2007. vol. 38. pp. 6981.

Schmalensee R. The Control of Natural Monopolies. - Lexington Mass.: Lexington Books, 2011. 258 p. 